\title{
EFFECTS OF IRRIGATION ON CROPS AND SOILS WITH RAFT RIVER GEOTHERMAL WATER
}

\author{
Norman E. Stanley \\ Richard C. Schmitt
}

Published January 1980

EG\&G Idaho, Inc. Idaho Falls, Idaho 83415

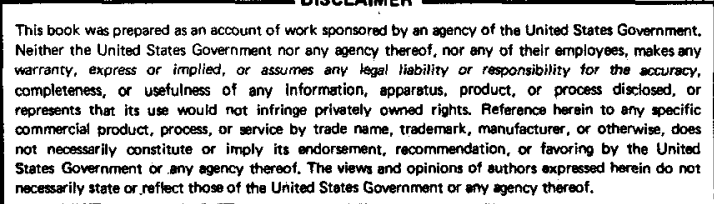

This book was prepared as an account of work sponsored by an ageney of the United States Government. This book was prepared as an account of work sponsored by an ajency of the United States Government.
Neither the United States Government nor any ageney thereot, nor any of theit employees, makes any weither the Unted States Government nor sny asency thereol, nor any or thelt employees, makes any completeness, of usefulness of any information, apparetus, product, or orocess discosed. or represents that its use would not infringe privately owmed rights, Reference herein to any specific commercial product, process, or sevvice by trade name, trodemark, manufacturer, of otherwise, does

not necessarily constitute or imply its endorsement, recommendation, of favoring by the United States Government or any agency thereot. The views and opinions of authors expressed herein do nol necessarily state or reffect those of the United States Government or my mency thereof.

Prepared for the

U.S. Department of Energy

Idaho Operations Office

Under DOE Contract No. DE-AC07-76ID01570 


\section{DISCLAIMER}

This report was prepared as an account of work sponsored by an agency of the United States Government. Neither the United States Government nor any agency Thereof, nor any of their employees, makes any warranty, express or implied, or assumes any legal liability or responsibility for the accuracy, completeness, or usefulness of any information, apparatus, product, or process disclosed, or represents that its use would not infringe privately owned rights. Reference herein to any specific commercial product, process, or service by trade name, trademark, manufacturer, or otherwise does not necessarily constitute or imply its endorsement, recommendation, or favoring by the United States Government or any agency thereof. The views and opinions of authors expressed herein do not necessarily state or reflect those of the United States Government or any agency thereof. 


\section{DISCLAIMER}

Portions of this document may be illegible in electronic image products. Images are produced from the best available original document. 


\section{ABSTRACT}

The Raft River Irrigation Experiment investigated the suitability of using energyexpended geothermal water for irrigation of selected field-grown crops. Crop and soil behavior on plots sprinkled or surface irrigated with geothermal water was compared to crop and soil behavior on plots receiving water from shallow irrigation wells and the Raft River. In addition, selected crops were produced, using both genthermal irrigation water and special management techniques. Crops irrigated with geothermal water exhibited growth rates, yields, and nutritional values similar to comparison crops. Cereal grains and surface-irrigated forage crops did not exhibit elevated fluoride levels or accumulations of heavy metals. However, forage crops sprinkled with geothermal water did accumulate fluorides, and leaching experiments indicate that new soils receiving geothermal water may experience increased salinity, exchangeable sodium, and decreased permeability. Soil productivity may be maintained by leaching irrigations. 


\section{FOREWORD}

The Raft River Geothermal Test Site in southcentral Idaho is operated as part of the Idaho National Engineering Laboratory, sponsored by the Department of Energy. EG\&G Idaho is the prime contractor. The experimental work conducted at the site is part of a national program designed to investigate the practical use of moderate-temperature geothermal energy for electric power production and for substitution for fossil fuels in direct heat applications. The work in this report examines the benefits of fluid disposal by irrigation using geothermal fluids quite similar to those expected following a primary energy extraction power generation or direct application step. 


\section{ACKNOWLEDGMENTS}

The authors express their appreciation to Dr. J. F. Kunze, a private energy consultant (formerly Manager of Geothermal Projects, EG\&G Idaho), under whose guidance this experiment was initiated; R. J. Schultz, Manager, Geothermal Program Management and Technology Transfer, EG\&G Idaho, for his leadership throughout much of this experiment;
Professors A. A. Bishop and H. B. Peterson, Utah State University Agriculture and Irrigation Engineering Department, for their able guidance and assistance throughout the experiments; and to Raft River farmers L. Udy, R. S. Stewart, and I. Darrington, for their cooperation in making land and water available for comparison in the experiment. 


\section{CONTENTS}

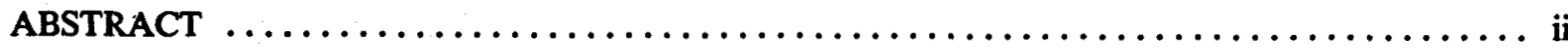

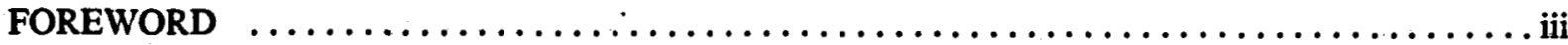

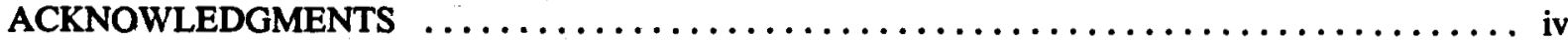

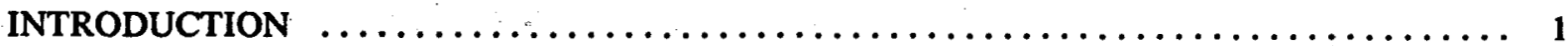

Problem Statement $\ldots \ldots \ldots \ldots \ldots \ldots \ldots \ldots \ldots \ldots \ldots \ldots \ldots \ldots \ldots \ldots \ldots \ldots \ldots \ldots$

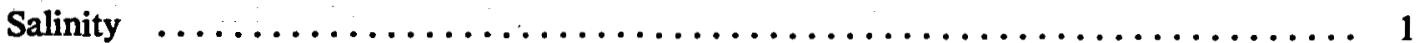

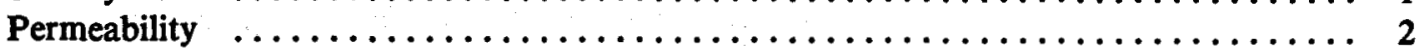

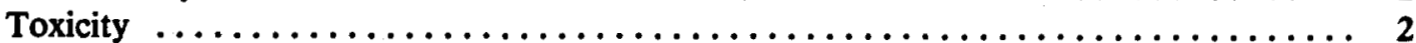

Experiment Phases $\ldots \ldots \ldots \ldots \ldots \ldots \ldots \ldots \ldots \ldots \ldots \ldots \ldots \ldots \ldots \ldots \ldots \ldots \ldots \ldots$

EXPERIMENT DESCRIPTION $\ldots \ldots \ldots \ldots \ldots \ldots \ldots \ldots \ldots \ldots \ldots \ldots \ldots \ldots \ldots \ldots \ldots$

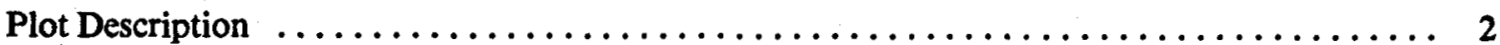

Crops Selected $\ldots \ldots \ldots \ldots \ldots \ldots \ldots \ldots \ldots \ldots \ldots \ldots \ldots \ldots \ldots \ldots \ldots \ldots \ldots \ldots$

Irrigation System and Scheduling $\ldots \ldots \ldots \ldots \ldots \ldots \ldots \ldots \ldots \ldots \ldots \ldots \ldots \ldots \ldots$

SAMPLES, ANALYSES, AND RESULTS $\ldots \ldots \ldots \ldots \ldots \ldots \ldots \ldots \ldots \ldots \ldots \ldots \ldots \ldots \ldots \ldots \ldots \ldots \ldots$

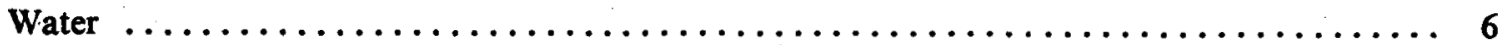

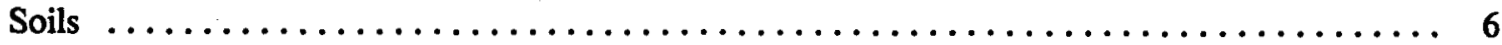

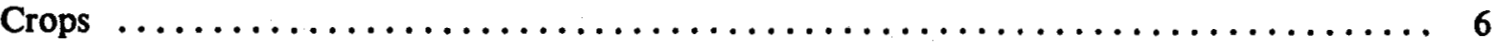

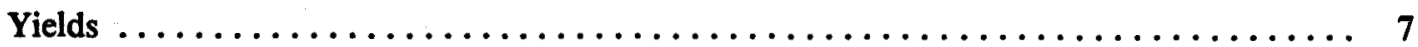

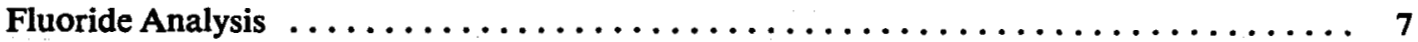

OBSERVATIONS AND DISCUSSIONS $\ldots \ldots \ldots \ldots \ldots \ldots \ldots \ldots \ldots \ldots \ldots \ldots \ldots \ldots$

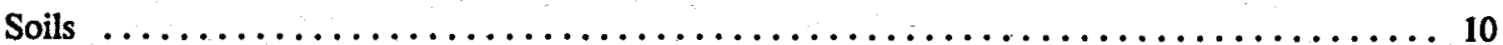

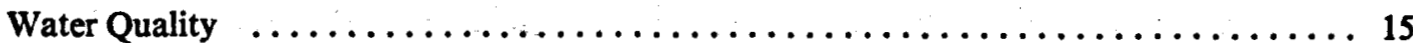

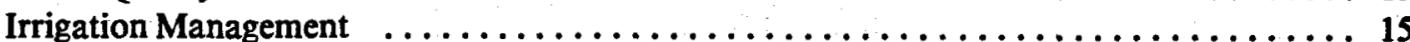

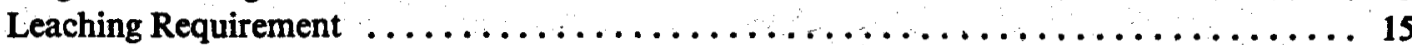

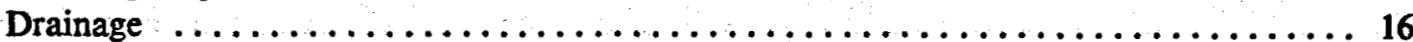

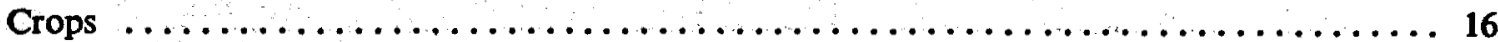

Growth and Yields ..................................... 16

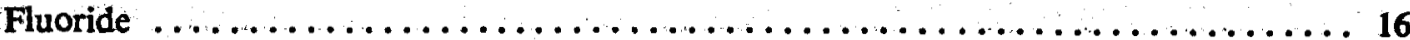

CONCLUSIONS AND RECOMMENDATIONS $\ldots \ldots \ldots \ldots \ldots \ldots \ldots \ldots \ldots \ldots \ldots \ldots \ldots$

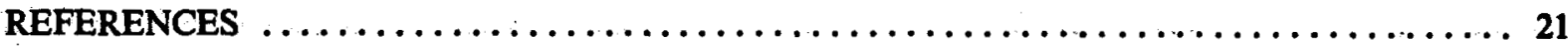




\section{FIGURES}

1. Location of the Raft River Geothermal Site, wells, and irrigation experiment plots $\ldots \ldots \ldots \ldots 3$

2. Plot layout by phase of the Raft River Geothermal Irrigation Experiment $\ldots \ldots \ldots \ldots \ldots \ldots$

3. Diagram for classifying irrigation waters $\ldots \ldots \ldots \ldots \ldots \ldots \ldots \ldots \ldots \ldots \ldots \ldots \ldots$

4. Barley plot sprinkled by geothermal water, showing good growth near sprinkler

lines where soils were leached effectively $\ldots \ldots \ldots \ldots \ldots \ldots \ldots \ldots \ldots \ldots \ldots \ldots \ldots$

5. Barley plot sprinkled by geothermal water, showing poor growth midway

between sprinkler lines where soils were not leached effectively $\ldots \ldots \ldots \ldots \ldots \ldots \ldots \ldots \ldots 18$

6. Typical threshed grains from experiment $\ldots \ldots \ldots \ldots \ldots \ldots \ldots \ldots \ldots \ldots \ldots \ldots$

7. Forage subplot sprinkled by geothermal water on soil at Ayses-Hiko Peak Complex ...... 19

8. Forage subplot sprinkled by comparison water, showing good growth of alfalfa

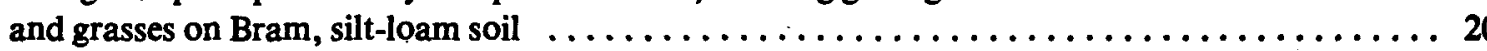

\section{TABLES}

1. Field, Vegetable, and Tree Species Cultured in the Raft River Irrigation Experiment Plots $\ldots . .5$

2. Water Chemistry of Irrigation Waters $\ldots \ldots \ldots \ldots \ldots \ldots \ldots \ldots \ldots \ldots \ldots \ldots \ldots \ldots \ldots$

3. Analytical Data on Soil from the Udy-1, Udy-2, and Stewart Trial Areas $\ldots \ldots \ldots \ldots$

4. Salt Exchange Capacity and Exchangeable Sodium Content of Brush Soil near

RRGE 2, with and without Geothermal Water $\ldots \ldots \ldots \ldots \ldots \ldots \ldots \ldots \ldots \ldots \ldots$

5. Salinity and Alkalinity of Udy-1 Soils, Before and After Leaching with Geothermal Water .... 10

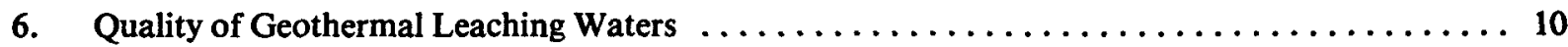

7. Analyses Data of the Soil Samples from the Udy-1 Irrigation Plots,

Following 3 Years of Irrigation

8. Composition of Phase-1 Barley, According to the Source and Application of Irrigation

Water

9. Composition of Phase-1 Alfalfa, According to the Source and Application of Irrigation

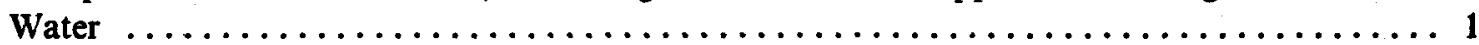

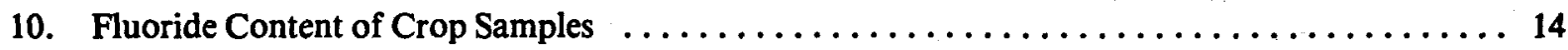




\section{EFFECTS OF IRRIGATION ON CROPS AND SOILS WITH RAFT RIVER GEOTHERMAL WATER}

\section{INTRODUCTION}

Geothermal energy projects in the planning and development stage today generally plan to follow the practice of injecting the geothermal brine into the aquifer after extracting heat from it. The theory is that injection will (a) dispose of an unuseful brine while guarding against possible environmental disruption, (b) maintain reservoir pressures, (c) reduce possible subsidence or seismicity, and (d) augment extraction of thermal water from reservoir rocks in areas of poor aquifer recharge. However, actual experience with injection is limited, and drilling and operating injection wells are costly. In fact, the high cost of injection, if a requirement, may well prohibit the development of geothermal energy for many small users. Alternate, environmentally acceptable methods of disposal are needed, particularly if disposal can be coupled to a beneficial use of the water.

Heretofore, beneficial uses for heat-expanded geothermal water, such as crop irrigation, aquaculture, and industrial washing operations, have been given little consideration. But as the use of geothermal energy advances, large quantities of these waters will become available for such purposes. Also, many known geothermal resource areas coincide with areas of chronic water shortage, and geothermal water may be a valuable additional source for agriculture on currently unproductive lands. Understanding the environmental effects that will result when soils, plants, and animals are exposed to geothermal waters is important for these reasons and for geothermal energy development in general. The irrigation experiment at the Raft River Geothermal Test Site encompasses 3 years of field trials designed to evaluate the feasibility of using geothermal water for irrigated crop production, thus contributing to the information needed to evaluate total use concepts for geothermal fluids.

\section{Problem Statement}

The suitability of geothermal water for agricultural irrigation is determined by the amount and kind of salts present, and upon the characteristics of the receiving crops and soils. Raft River geothermal irrigation water is classified as exhibiting medium to very high salinity and sodium hazards that will likely lead to the development of soil or cropping problems unless special management practices are implemented to maintain suitable crop productivity.

The potential problems surrounding the use of Raft River geothermal water for irrigation vary, depending upon the water characteristics (water quality varies among production-well locations), soil characteristics, and crop variety. The problems are explained below.

\section{Salinity}

Irrigation-related salinity usually occurs on poorly drained soils, or soils above high water tables. When geothermal water containing approximately $1.5 \mathrm{~kg}$ salts $/ \mathrm{m}^{3}$ (typical of Raft River geothermal water) is applied to soils at an annual rate of 6000 to $14000 \mathrm{~m}^{3} / \mathrm{ha}$, considerable quantities of salts are added to the soils over a few years. On poorly drained soils, much of the water is lost through evapotranspiration, leaving the salts in the root zone. If irrigations cause the water table to rise to within 1 to $2 \mathrm{~m}$ of the soil surface, ground water moves upward by capillary action into the root zone and soil surface. Under this condition, ground water, as well as irrigation water, may contribute to salinity. High salinity in soils may impair crop production by increasing the osmotic pressure of the soil solution and increasing soil-moisture tension as the soil dries, thus reducing the availability of water to plants. 
Increased quantities of salts in the soil solution may also hinder the entrance of nutrient ions into root hairs, resulting in nutritional imbalances in the crop.

\section{Permeability}

Geothermal water with a high sodiumadsorption ratio will increase the amount of exchangeable sodium in most soils. As sodium ions are adsorbed, deflocculation of soil colloids may occur, resulting in a breakdown of the structural units of the soil. This condition causes the soil to become less pervious to water, reducing the water supply to crop roots. In fine-textured soils, deflocculation may also impede root penetration and reduce aeration, restricting root respiration and setting up anaerobic conditions that may produce toxic compounds.

\section{Toxicity}

Toxicity occurs within a crop as a result of the uptake and accumulation of certain constituents from the irrigation water. The constituents of major concern in Raft River geothermal water are sodium, chloride, and fluoride. Crop plants exhibit a wide range of sensitivity to these elements. Water containing these ions is absorbed by the plants, and much of the water is transpired from the leaves leaving the ions behind. Damage occurs when the sodium, chloride, and fluoride ions accumulate to concentrations which exceed the tolerance of the crop. Characteristic symptoms usually include leaf burn, drying, and necrosis of the tissue beginning at the outer edges and tip of the leaf. As severity increases, the burning progresses inward, between leaf veins and toward the center. The damage may reduce both the quantity and quality of the crop.

High levels of fluorides that accumulate in feed and food crops may also contribute to fluoride toxicity in consuming organisms. Signs of excessive fluoride ingestion in livestock usually include dental and osseous lesions, and lameness.

\section{Experiment Phases}

The experiment was initiated with the 1976 (Phase-1) growing season, and continued through the 1977 (Phase-2) and 1978 (Phase-3) seasons. Previous reports 1,2 provide detailed descriptions of Phases-1 and -2 activities and results, and contain appendixes of plot soil descriptions and guidelines for quality ratings of irrigation water.

\section{EXPERIMENT DESCRIPTION}

In addition to the overall objectives of the experiment regarding the feasibility of irrigation as a beneficial use for low-salinity geothermal fluid, and to understanding some of the environmental implications of this application, further objectives are

1. To provide a field experiment of sufficient scale for meaningful data on geothermalfluid effects on field crops

2. To examine plant behavior, tolerance, yield, and uptake of heavy metals and fluorides, when irrigated wholly or partially with geothermal waters in surface and sprinkler irrigation

3. To examine changes in root-zone soils following soil irrigation with geothermal waters

4. To accumulate a data base on problems that might be encountered during geothermal crop raising.

\section{Plot Description}

The experiments were conducted on a 13.2-ha tract of land located near the Raft River Geothermal Test Site in south-central Idaho (see Figure 1). The land was divided into three plots and several subplots to facilitate the tests performed during each experiment phase. Figure 2 shows the layout of the plots and subplots for each experiment 


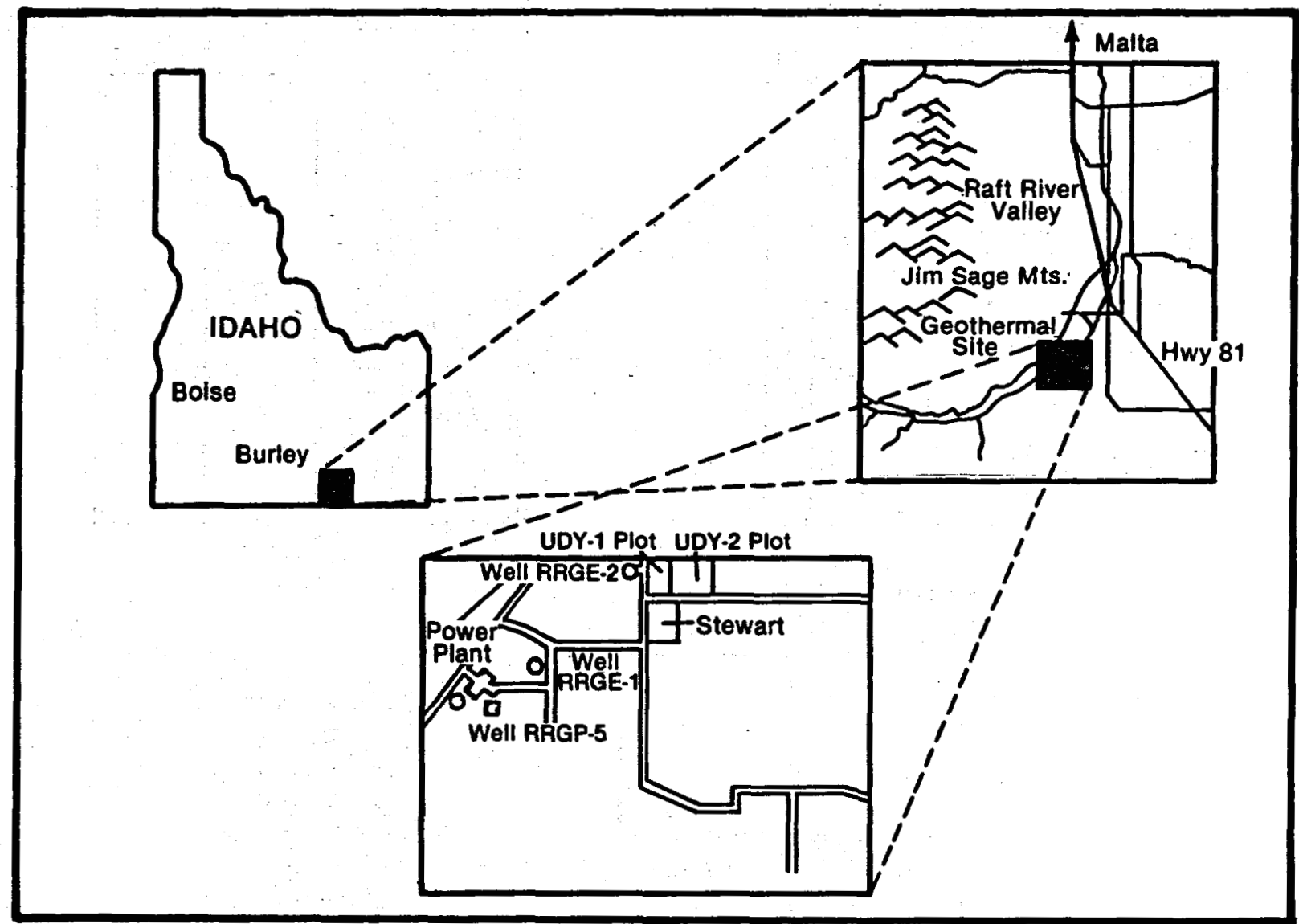

INĖL-A-12 961-2

Figure 1. Location of the Raft River Geothermal Site, wells, and irrigation experiment plots.

phase, indicating the source of irrigation water, mode of application, and crops cultured.

The 2.8-ha Stewart plot was located on Sweetzer silt-loam soil, characterized by a $33-\mathrm{cm}$ silt-loam surface layer overlying a stratified substratum. This plot, used only during Phase 1 (1976) of the experiment, had a history of cultivation with the principal source of water being an existing shallow aquifer well.

The Udy-1 and -2 plots were untilled and supported sagebrush-community vegetation prior to these tests. Udy 1 was first tilled during Phase 1 and was used during all three experiment phases. Udy 2 was first tilled during Phase 2 and was used again during Phase 3. The Udy plots were located predominately on Bram, silt-loam soil, typically composed of a $10-\mathrm{cm}$ thick, silt-loam surface layer underlain by silty clay loam to a depth of $150 \mathrm{~cm}$. The soil is strong-to-very-strong alkaline and calcareous with a concentration of lime between
10 and $75 \mathrm{~cm}$. Permeability on these soils is moderately slow.

A narrow strip of Ayses-Hiko Peak-Complex soil characterized by a $15-\mathrm{cm}$ surface loam, underlain by gravel and sand loams, was located along the north margin of the Udy-1 and -2 plots. This soil is calcareous, alkaline, saline, and excessively drained.

The experiment plots were selected primarily for availability and proximity to water sources. At the time of plot selection, no soil survey information was available. The plot soils are highly variable, which has required random collection of crop samples from all subplots. Data of crop yields from geothermal-irrigated plots are compared only to the area average. No yield comparisons between plots or subplots were attempted.

Irrigation water for the geothermal-irrigated subplots was obtained from two 1500-m deep 
Phase 1 (1976)
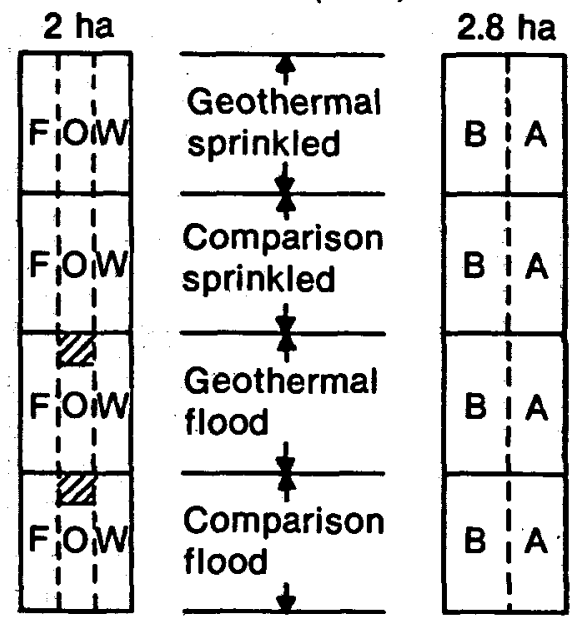

Phase 2 (1977)

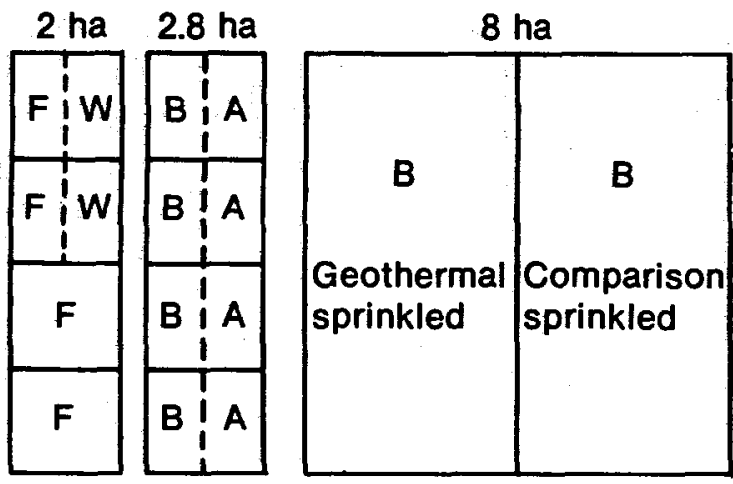

Phase 3 (1978)
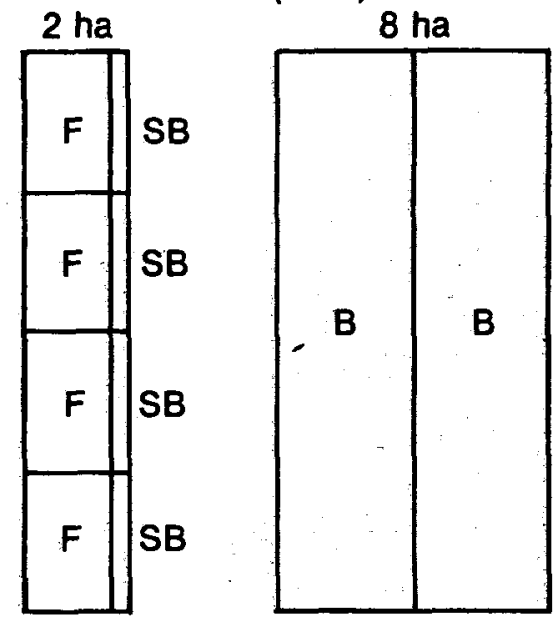

$$
\begin{aligned}
T & =\text { Hardwood trees } \\
F & =\text { Forage mix } \\
O & =\text { Oats } \\
W & =\text { Wheat } \\
\mathbb{Z} & =\text { Vegetables } \\
B & =\text { Barley } \\
A & =\text { Alfalfa } \\
S B & =\text { Sugar beets } \\
\text { SC } & =\text { Specialty crops }
\end{aligned}
$$

INEL-A-13 910

Figure 2. Plot layout by phase of the Raft River Geothermal Irrigation Experiment.

geothermal wells, identified as RRGE 1 and RRGE 2 on Figure 1. The comparison water was obtained from the Raft River during Phase 1 and from existing, shallow irrigation wells during Phases 2 and 3. Drought conditions experienced during the latter two experiment phases eliminated the availability of Raft River water and necessitated the change.

\section{Crops Selected}

In selecting crops to evaluate the effects of geothermal irrigation, consideration was given to the nature of the local soils, climate, water characteristics, local farming practices, and possible alternatives. The growing season in the Raft River Valley is short, having an average, frost-free growing period of only about 120 days. Also, many of the local soils and irrigation waters are saline. These adverse conditions limit the productivity of many crop varieties. Consequently, most of the crops cultured in the area are hardy and salt tolerant. The crops selected for this study are adapted to the local climate and, for sampling purposes, represent a range of salt tolerance. Figure 2 shows the crop distribution on the plots for each experiment phase. Table 1 lists the crop species grown, and their relative salt tolerance.

Crop management and timing were in keeping with recommendations from Utah State University Irrigation Engineering Department and University of Idaho Agricultural Extension Service consultants. Local farmers were contracted to -perform crop production activities requiring mechanized equipment, e.g., tilling, seeding, cultivating, and harvesting. 


\section{TABLE 1. FIELD, VEGETABLE, AND TREE SPECIES CULTURED IN THE RAFT RIVER IRRIGATION EXPERIMENT PLOTSa}

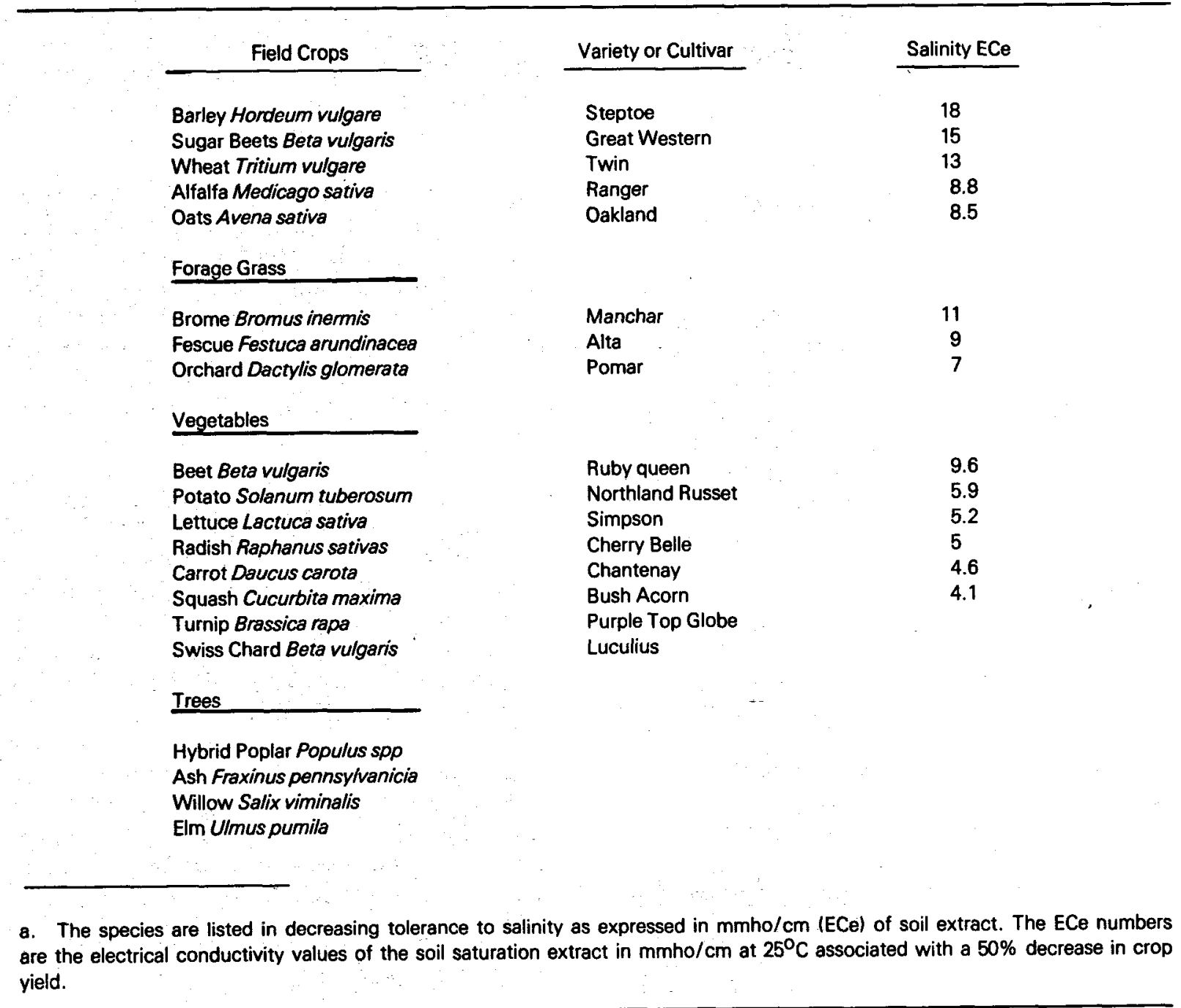

\section{Irrigation System and Scheduling}

The irrigation systems consisted of $15.2-\mathrm{cm}$ aluminum main lines and $7.6-\mathrm{cm}$ lateral lines on sprinkled subplots, and $15.2-\mathrm{cm}$ gated, surfacepipe laterals on the surface flood sections. The lateral lines were spaced $15.4 \mathrm{~m}$ on center, with sprinkler heads $9.2 \mathrm{~m}$ apart. Full circle impact sprinkler heads with $0.36-\mathrm{cm}$ nozzles were placed on 91-cm risers. Each lateral line (sprinkler and gated pipe) was controlled with a valve. At the top of each surface-irrigated plot, only one lateral line was required. The pipe gates were $76 \mathrm{~cm}$ apart, on center. Water was supplied to the plots via pumps located near the Raft River, RRGE-2 geothermal well, and the L. Udy farm. The water application rate was about $0.6 \mathrm{~cm} / \mathrm{ha}$ of water per hour.

During Phase 1, extensive meteorological data were collected and analyzed; evapotranspiration potentials were calculated; and irrigations scheduled in an attempt to provide the consumptive irrigation requirements to plot crops. However, this approach met with some difficulty due to variability in the individual crop requirements across the plots, nonuniformity of leaching requirements for the soil types present, irregular water supply availability, and pumping system failures.

Subplot design for Phases-2 and - $\mathbf{3}$ experiments was changed to achieve crop water requirement 
compatibility across the plots. Irrigation scheduling was based upon classic, consumptive irrigation requirements for Strevell, Idaho, ${ }^{3}$ a weather monitoring station located approximately $24 \mathrm{~km}$ northeast of the experiment plots. In general, plots were irrigated every 10 days from mid-May through mid-September, with approximately $8 \mathrm{~cm}$ of water applied per irrigation.

\section{SAMPLES, ANALYSES, AND RESULTS}

An extensive sampling and analysis program was employed to characterize irrigation waters and to evaluate their effects upon soils and crops. The sample analysis program included thorough baseline characterizations during Phase 1 , and follow-up analyses during Phases 2 and 3, concentrating on fluoride accumulation in crops- and salt-related problems in soils.

\section{Water}

Water from the two geothermal wells, the Raft River, and comparison irrigation wells was sampled and analyzed periodically during the irrigation seasons by technicians from EG\&G and the State of Idaho Department of Water Resources. The Phase-1 analysis provided a thorough characterization of the water constituents, whereas Phases- 2 and -3 analyses concentrated on conductivity (ECw), SAR, pH, fluoride, chloride, total hardness, and silica. Results of the water analyses are shown in Table 2.

The most important quality characteristics of an irrigation are (a) total concentration of soluble salts, (b) relative proportion of sodium to other cations, and (c) concentration of toxic elements, such as fluoride or boron. (The effects of high salinity, sodium, and fluoride were briefly discussed in the Problem Statement of the Introduction.) Figure 3 shows a diagram for determining the quality rating of an irrigation water from its electrical conductivity and sodium adsorption ratio, with symbols indicating the classifications of waters compared in this experiment.

\section{Soils}

A general preexperiment evaluation of the salinity of plot soils was obtained by collecting random 0- to $25-\mathrm{cm}$ deep soil samples across each plot, and compositing them for analysis. The results of these initial analyses were compared with data from subsequent tests, which included a laboratory leaching experiment, a single irrigation field test, and 3 years of geothermal irrigations on the Udy-1 plots. The results of the initial soil analyses are found in Table 3.

The short-term effects of geothermal water on new soils was determined in the field on a small plot of uncultivated, sagebrush-community soil. A portion of the soil was irrigated with geothermal water for 24 hours. Following the irrigation, soil samples were collected from the irrigated and adjacent nonirrigated soils, analyzed, and compared for soil salinity. The results of these analyses are shown in Table 4.

In the laboratory, a composite-bulk soil sample, collected from the 0 - to 15 -cm depth of Udy 1 , was placed in a column and leached with $3 \mathrm{~m}$ of geothermal water. The soil was subsequently analyzed and the results compared to the initial evaluation soil data. The results of these soil analyses and the chemistry of the leaching waters are shown in Tables 5 and 6.

The long-term effects of geothermal irrigation were investigated by sampling and analyzing Udy-1 plot soils at two locations on each subplot, following the three seasons of water application. The samples were analyzed individually to provide an index of the variation that may be encountered across the plot. Table 7 shows the results of the 3 year soil analyses.

\section{Crops}

The geothermal water contained a high level of fluoride and traces of other potentially toxic elements. A major concern regarding the use of this water for irrigation was that crop productivity, nutritional value, or edibility might be impaired if plants accumulated toxic substances from the water. During Phase 1, samples of mature oats, wheat, barley, grasses, alfalfa, and potatoes were irrigated with geothermal and comparison waters, collected, and analyzed for total constituents [using chemical- and neutronactivation (NAA) techniques] and for nutritional values. The geothermal-irrigated crops were compared to control-plot crops and to composition data from the literature. The Phase-1 comparisons 


\section{TABLE 2. WATER CHEMISTRY OF IRRIGATION WATERS (Season Averages, Values in ppm)}

\begin{tabular}{|c|c|c|c|c|c|c|c|}
\hline & \multicolumn{3}{|c|}{ Phase 1} & \multicolumn{2}{|c|}{ Phase 2} & \multicolumn{2}{|c|}{ Phase 3} \\
\hline & Geothermal & $\begin{array}{l}\text { Raft } \\
\text { River }\end{array}$ & $\begin{array}{c}\text { Comparison } \\
\text { Well }\end{array}$ & Geothermal & $\begin{array}{c}\text { Comparison } \\
\text { Well }\end{array}$ & Geothermal & $\begin{array}{c}\text { Comparison } \\
\text { Well }\end{array}$ \\
\hline$E C w$ & 2850 & 1160 & 2480 & 3100 & 2500 & 2800 & 2480 \\
\hline SAR & 21.1 & 2.6 & & 17.9 & 9 & & 9 \\
\hline $\mathrm{pH}$ & 8.3 & 8.2 & 7.7 & 8 & 7.5 & 8.2 & 7.6 \\
\hline$B$ & 0.19 & 0.10 & 0.1 & & & & \\
\hline $\mathrm{Ca}$ & 53 & 82 & 97 & & & & \\
\hline $\mathrm{Fe}$ & & 0.15 & $<0.1$ & & & & \\
\hline$k$ & 39 & 7.1 & 16.5 & & & & \\
\hline $\mathrm{Li}$ & 1.6 & $<0.1$ & 1.2 & & & & \\
\hline $\mathrm{Mg}$ & 0.57 & 19 & 10 & & & & \\
\hline $\mathrm{Na}$ & 564 & 72 & 536 & & & & \\
\hline $\mathrm{Ni}$ & 0.01 & & & & & & \\
\hline$P$ & $<0.1$ & 2.5 & 0.01 & & & & \\
\hline $\mathrm{Si}$ & 70 & & & & & & \\
\hline $\mathrm{SiO}_{2}$ & 180 & 38 & 58 & 180 & 50 & 182 & 42 \\
\hline Sr & 1.4 & & & & & & \\
\hline $\mathrm{Cl}^{-}$ & 936 & 133 & 895 & 936 & 664 & 837 & 686 \\
\hline $\mathrm{CO}_{3}$ & 14.2 & & & & & & \\
\hline $\mathrm{F}^{-}$ & 9.4 & 0.61 & 3.6 & 9.4 & 2 & 10.4 & 2 \\
\hline $\mathrm{HCO}_{3}$ & 26.8 & 248 & 169 & 124 & 199 & 150 & 202 \\
\hline $\begin{array}{l}\mathrm{NH}_{4} \\
\mathrm{SO}_{4}\end{array}$ & 0.1 & 54 & 74 & & & & \\
\hline
\end{tabular}

indicated no significant differences in growth, yields, or nutritional values between crops irrigated with geothermal and comparison waters. Geothermal-sprinkled crops exhibited elevated levels of fluoride, but were otherwise similar in elemental composition to comparison and reference-data crops. On the following pages, the constituents of barley (Table 8) and alfalfa (Table 9) are listed, as well as the analyses of the various constituents by both chemical- and neutron-activation methods.

\section{Yields}

Estimates indicate essentially no difference in yields between crops receiving geothermal or comparison waters. Yields also compared favorably with crops grown in the surrounding farm area. For example, the barley grown on the newly tilled Udy-2 plot during Phase 2 yielded $2581 \mathrm{~kg} / \mathrm{ha}$, which was lower than the area average $(\sim 3657 \mathrm{~kg} / \mathrm{ha})$, but not uncommon for first-year production on new soil. During Phase 3, the
Udy-2 plot barley yielded $\sim 5273 \mathrm{~kg} / \mathrm{ha}$, which was greater than average yields in the area. 7

\section{Fluoride Analyses}

Since geothermal water often contains soluble salts, traces of heavy metals, and fluoride (6 to $10 \mathrm{ppm}$ at Raft River), an objective of the Raft River Experiment was to evaluate crop constituents after exposure to geothermal fluids. Analyses of crop constituents during Phase 1 indicated that geothermal-irrigated crops do not accumulate excessive heavy metals or minerals. But the cereal grains exhibited elevated fluoride concentrations, primarily as adsorbed surface contamination. The fluoride levels prompted concern over possible high-fluoride concentration in livestock forage crops. Plants and animals exhibit varying degrees of fluoride sensitivity. Accumulation of fluorides in sensitive plants can result in changes in their metabolism, production of foliar lesions, and alterations in growth, development, and yield. Their sensitivity is usually to gaseous 


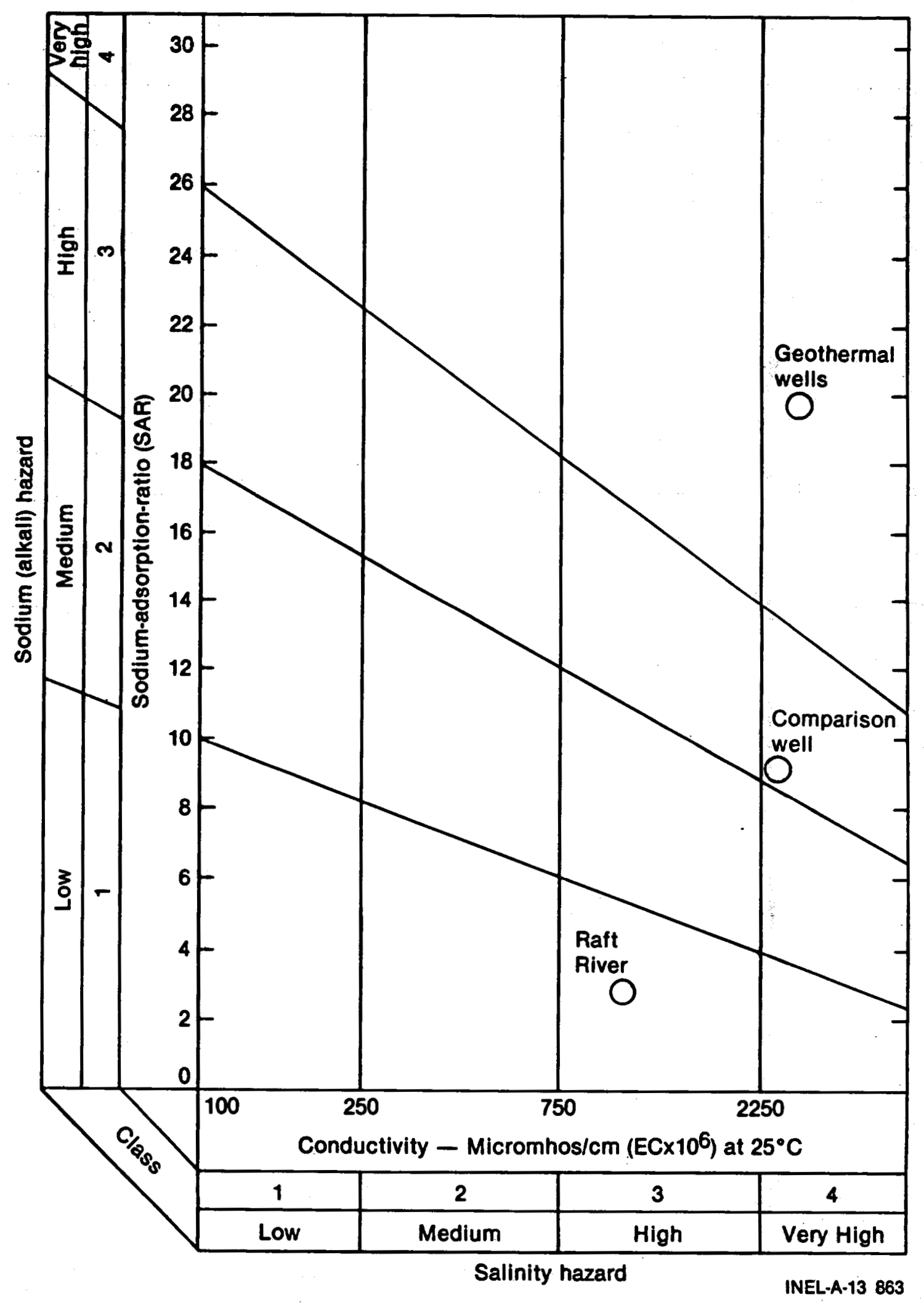

Figure 3. Diagram for classifying irrigation waters. ${ }^{4}$ 
TABLE 3. ANALYTICAL DATA ON SOIL FROM THE UDY-1, UDY-2, AND STEWART TRIAL AREAS

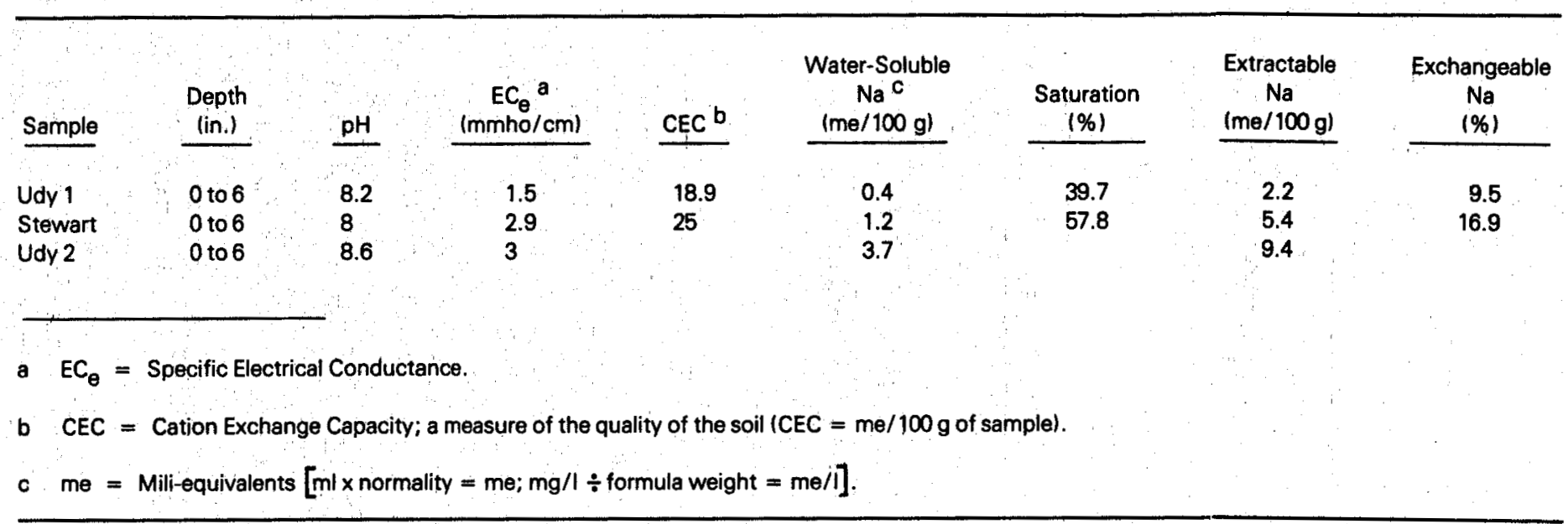

TABLE 4. SALT EXCHANGE CAPACITY AND EXCHANGEABLE SODIUM CONTENT OF BRUSH SOIL NEAR RRGE 2, WITH AND WITHOUT GEOTHERMAL WATER

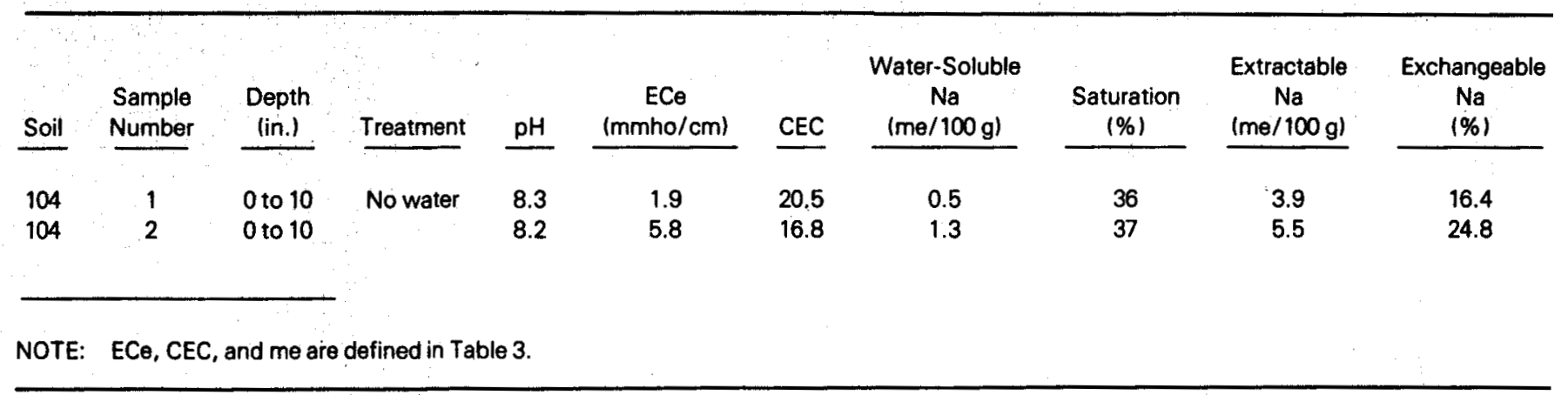


TABLE 5. SALINITY AND ALKALINITY OF UDY-1 SOILS, BEFORE AND AFTER LEACHING WITH GEOTHERMAL WATER

\begin{tabular}{|c|c|c|c|c|c|c|c|}
\hline \multirow[b]{2}{*}{ Sample } & \multirow{2}{*}{$\frac{\begin{array}{c}\mathrm{NH}_{4} \mathrm{OAc} \\
(\mathrm{me} / 100 \mathrm{~g})\end{array}}{\mathrm{CEC}}$} & \multirow{2}{*}{$\frac{\begin{array}{c}\mathrm{H}_{2} \mathrm{O}-\mathrm{Sol} \\
(\mathrm{me} / 100 \mathrm{~g})\end{array}}{\mathrm{Na}}$} & \multirow[b]{2}{*}{$\mathrm{Na}$} & \multirow[b]{2}{*}{ ESP } & \multirow[b]{2}{*}{ SP } & \multirow[b]{2}{*}{$\mathrm{pH}$} & \multirow[b]{2}{*}{$\begin{array}{c}\text { ECe } \\
(\mathrm{mmho} / \mathrm{cm})\end{array}$} \\
\hline & & & & & & & \\
\hline Initial sample & 18.9 & 2.2 & 0.4 & 9.5 & 39 & 8.2 & 1.5 \\
\hline After leaching & 18.1 & 4.2 & 1.2 & 17 & 39 & 8.3 & 3.8 \\
\hline
\end{tabular}

TABLE 6. QUALITY OF GEOTHERMAL LEACHING WATERS

\begin{tabular}{|c|c|c|c|c|c|}
\hline Sample & $\underset{(\mathrm{me} / \mathrm{l})}{\mathrm{Ca}}$ & $\underset{(m e / l)}{\mathrm{Mg}}$ & $\underset{\text { (me/I) }}{\mathrm{Na}}$ & $\begin{array}{c}\text { ECe } \\
(\mathrm{mmho} / \mathrm{cm})\end{array}$ & SAR \\
\hline RRGE 1 and 2 & 3.2 & 0.1 & 23 & 3160 & 17.96 \\
\hline
\end{tabular}

forms of fluoride, such as hydrogen fluoride. The ingestion of excessive fluorides by animals may result in lesions on developing teeth, osseous lesions, lameness, and impairment of appetitewith related decreases in growth and milk yield. 8 Consequently, Phases-2 and -3 evaluations were designed to further evaluate crop composition with particular emphasis on accumulations of fluoride in forage crops.

Thus, samples of alfalfa, spring and fall barley, brome, fescue, and orchard grasses, sugar-beet tops, and wheat were collected and analyzed for composition (including fluoride) and nutritional value during the next two growing seasons. Samples of leaves and crowns of sugar beets collected from the Udy-1 subplots were included in the evaluations because they are commonly used as animal feed. The results of the fluoride determinations are shown in Table 10.

These data show that geothermal waters containing fluoride can be used for surface irrigation without greatly increasing the fluoride content of the forage being grown, but that fluorides are apparently absorbed by forage crops receiving sprinkled water. There is no indication that the seeds of cereal crops accumulate excessive amounts of fluoride when sprinkled with geothermal water.

\section{OBSERVATIONS AND DISCUSSIONS}

\section{Soils}

The Raft River soils are typically saline. This may be the result of a combination of factors, including salt constituents in the ground water and primary soil minerals, low rainfall, and poor surface drainage. Drainage of salt-bearing waters from the higher elevations may periodically raise the ground-water level to near the soil surface in the valley floor. Subsequent evaporation leaves behind dissolved salts, resulting in salinization of the soils. The presence of excessive salt in the soil increases soil-moisture tension and osmotic pressure of the soil solution, reducing water availability to plant roots and restricting growth. Some Raft River soils, called Saline-Alkali soils, contain appreciable quantities of exchangeable sodium, in addition to salt. The sodium-saturated clay materials in these soils are highly dispersed and may become transported downward through the soil, accumulating at lower levels in the soil profile where they develop a dense layer of low permeability.

When these soils are used for irrigated agriculture, leaching irrigations are required to 


\section{TABLE 7. ANALYSES DATA OF THE SOIL SAMPLES FROM THE UDY-1 IRRIGATION PLOTS, FOLLOWING 3 YEARS OF IRRIGATION}

\begin{tabular}{|c|c|c|c|c|c|c|c|c|c|c|c|c|c|c|}
\hline \multirow[b]{2}{*}{ Sample } & \multirow[b]{2}{*}{ Identity } & \multicolumn{3}{|c|}{$\begin{array}{c}\mathrm{NH}_{4} \mathrm{OAc}^{\mathrm{a}} \\
(\mathrm{meg} / 100 \mathrm{~g})\end{array}$} & \multicolumn{4}{|c|}{$\begin{array}{l}\text { Water soluble } \\
\text { (meg/100 g) }\end{array}$} & \multicolumn{2}{|c|}{$\begin{array}{l}\text { Exchangeable }{ }^{a} \\
(m e g / 100 \mathrm{~g})\end{array}$} & \multirow[b]{2}{*}{ ESP } & \multirow[b]{2}{*}{ SP } & \multirow[b]{2}{*}{$\mathrm{pH}$} & \multirow{2}{*}{$\begin{array}{c}E C_{\theta} \\
(\mathrm{mmho} / \mathrm{cm})\end{array}$} \\
\hline & & CEC & $\mathrm{Na}$ & K & $\mathrm{Na}$ & K & $\mathrm{Ca}$ & $\mathrm{Mg}$ & $\mathrm{Na}$ & K & & & & \\
\hline 1 & Geothermal flood, southwest corner & 18.3 & 4 & 5.9 & 1.2 & 0.1 & 0.2 & 0.1 & 2.8 & 5.8 & 15 & 41 & 7.9 & 4 \\
\hline 2 & $\begin{array}{l}\text { Comparison well sprinkled, plot } \\
\text { center }\end{array}$ & 16.6 & 3.1 & 4.3 & 0.8 & 0.1 & 0.2 & 0.1 & 2.3 & 4.2 & 14 & 41 & 8 & 2.6 \\
\hline 3 & $\begin{array}{l}\text { Comparison well flood, southwest } \\
\text { corner }\end{array}$ & 20.5 & 3.9 & 6 & 1.2 & 0.1 & 0.3 & 0.1 & 2.7 & 5.9 & 13 & 42 & 7.9 & 4.5 \\
\hline 4 & $\begin{array}{l}\text { Comparison well sprinkled, southeast } \\
\text { corner }\end{array}$ & 17.6 & 3.2 & 4.7 & 1.1 & 0.1 & 0.3 & 0.1 & 2.1 & 4.6 & 12 & 43 & 7.8 & 3.8 \\
\hline 5 & $\begin{array}{l}\text { Comparison well flood, southeast } \\
\text { corner }\end{array}$ & 19.4 & 5.2 & 7 & 1.6 & 0.2 & 0.5 & 0.1 & 3.6 & 6.8 & 19 & 44 & 7.5 & 5.7 \\
\hline 6 & Geothermal flood, center east & 18.7 & 5.7 & 4.7 & 2 & 0.2 & 0.5 & 0.2 & 3.7 & 4.5 & 20 & 47 & 7.8 & 6.2 \\
\hline 7 & $\begin{array}{l}\text { Geothermal sprinkled, northeast } \\
\text { corner }\end{array}$ & 18.7 & 4.9 & 4.7 & 0.7 & 0.1 & 0.1 & 0.1 & 4.2 & 4.6 & 23 & 41 & 8 & 2. \\
\hline 8 & $\begin{array}{l}\text { Geothermal sprinkled, southwest } \\
\text { corner }\end{array}$ & 17.6 & 4.3 & 4.5 & 0.7 & 0.1 & 0.1 & 0.1 & 3.6 & 4.4 & 21 & 44 & 8 & 1.9 \\
\hline
\end{tabular}

a. In the presence of lime, the exchangeable $\mathrm{Ca}$ and $\mathrm{Mg}$ cannot be accurately determined. 
TABLE 8. COMPOSITION OF PHASE-1 BARLEY, ACCORDING TO THE SOURCE AND APPLICATION OF THEIR IRRIGATION WATER

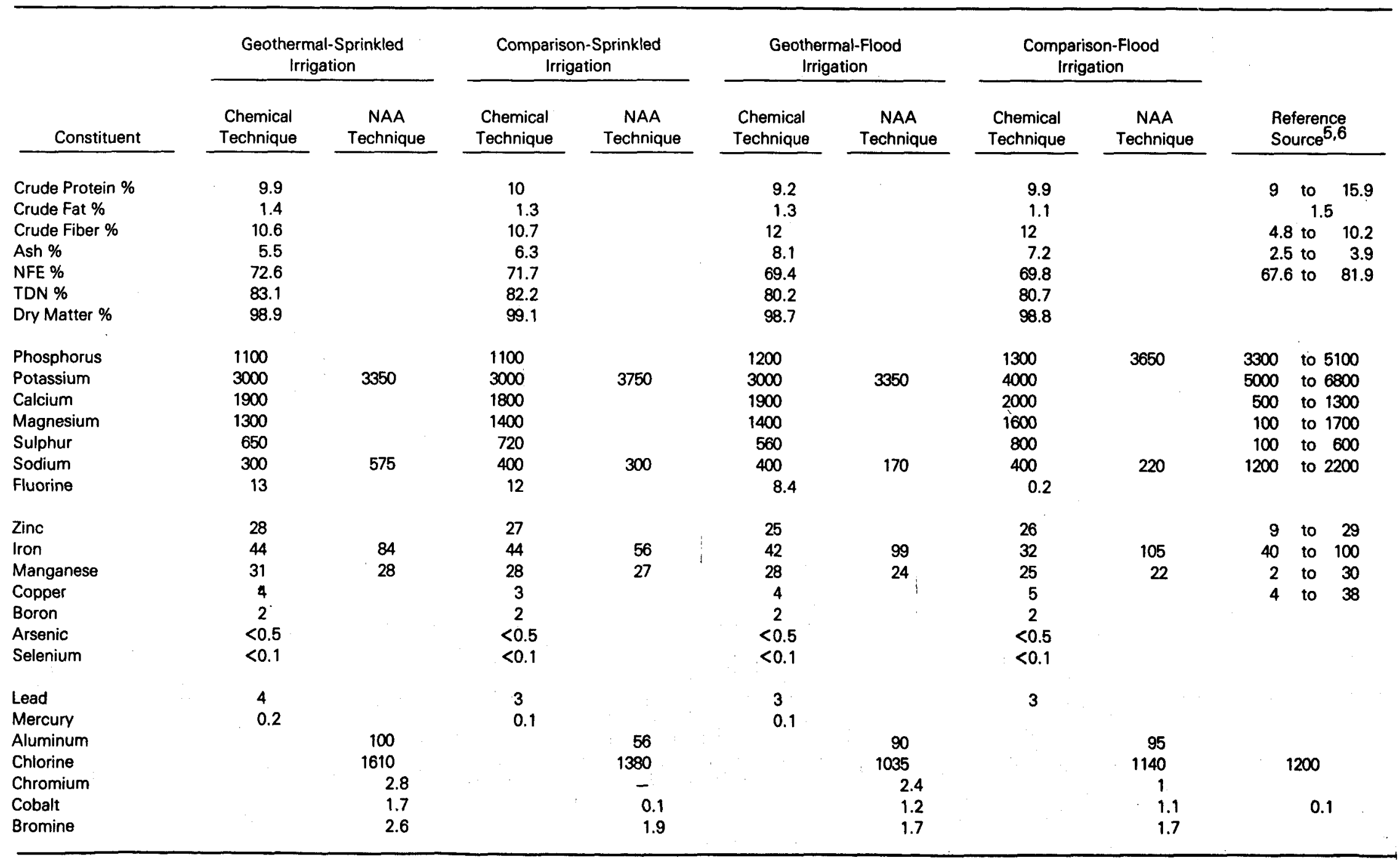


TABLE 9. COMPOSITION OF PHASE-1 ALFALFA, ACCORDING TO THE SOURCE AND APPLICATION OF IRRIGATION WATER

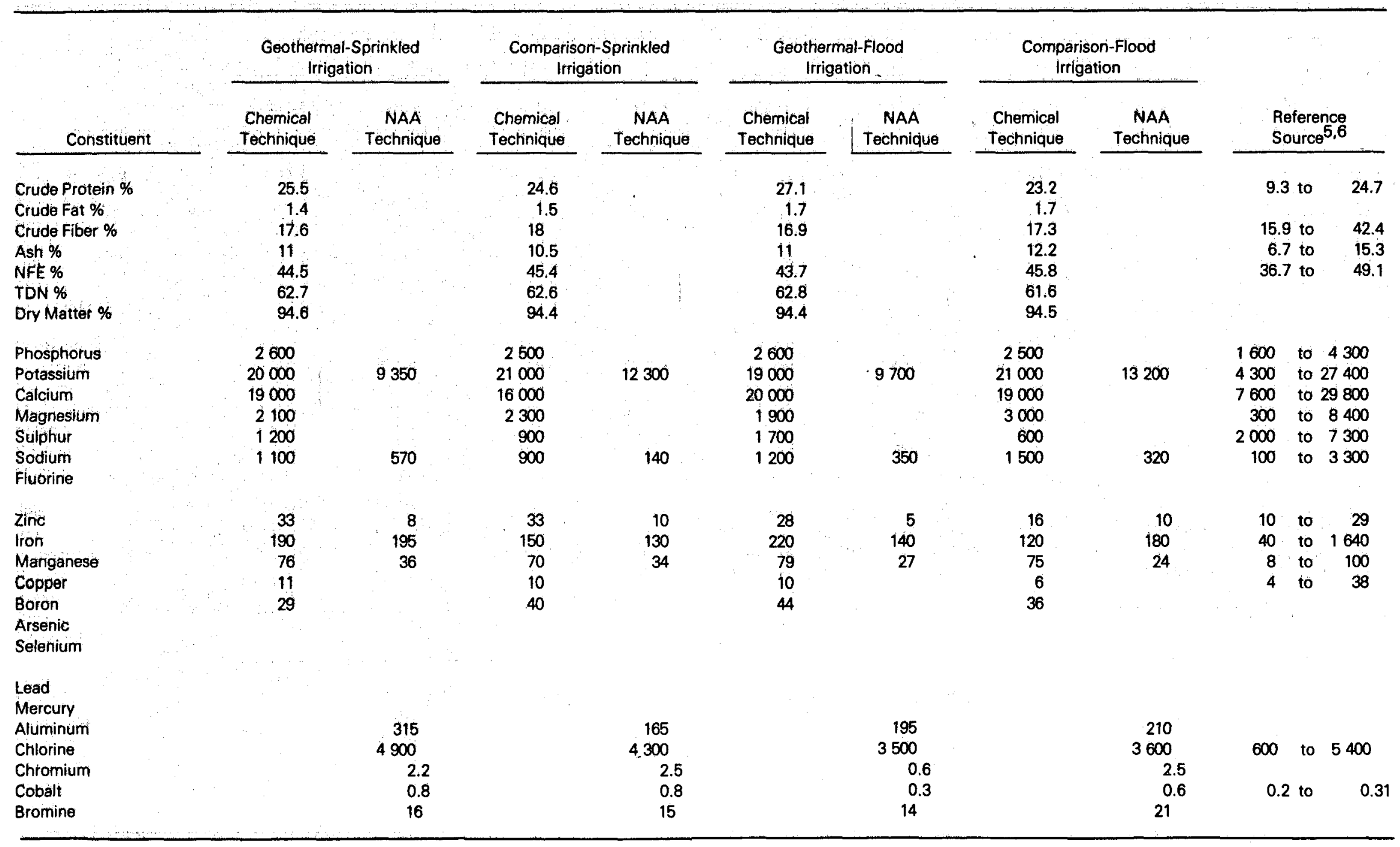


TABLE 10. FLUORIDE CONTENT OF CROP SAMPLES

\begin{tabular}{|c|c|c|c|c|c|c|c|c|c|c|}
\hline \multirow[b]{2}{*}{ Crop } & \multicolumn{4}{|c|}{ Phase $1(1976)$} & \multicolumn{2}{|c|}{ Phase 2 (1977) } & \multicolumn{4}{|c|}{ Phase 3 (1978) } \\
\hline & $\begin{array}{l}\text { Geothermal } \\
\text { Sprinkle } \\
\text { (9.4 ppm) }\end{array}$ & $\begin{array}{c}\text { Comparison } \\
\text { Sprinkle } \\
\text { (2 ppm) }\end{array}$ & $\begin{array}{l}\text { Geothermal } \\
\text { Flood } \\
(9.4 \mathrm{ppm})\end{array}$ & $\begin{array}{c}\text { Comparison } \\
\text { Flood } \\
(2 \mathrm{ppm})\end{array}$ & $\begin{array}{c}\text { Geothermal } \\
\text { Sprinkle } \\
\text { (9.4 ppm) }\end{array}$ & $\begin{array}{l}\text { Comparison } \\
\text { Sprinkle } \\
(2 \mathrm{ppm}) \\
\end{array}$ & $\begin{array}{c}\text { Geothermal } \\
\text { Sprinkle } \\
\text { (10.4 ppm) }\end{array}$ & $\begin{array}{c}\text { Comparison } \\
\text { Sprinkle } \\
\text { (2 ppm) }\end{array}$ & $\begin{array}{l}\text { Geothermal } \\
\text { Flood } \\
\text { (10.4 ppm) }\end{array}$ & $\begin{array}{c}\text { Comparison } \\
\text { Flood } \\
(2 \mathrm{ppm}) \\
\end{array}$ \\
\hline Alfalfa & & & & & 113 & 38 & 113 & 38 & 15 & 15 \\
\hline \multicolumn{11}{|l|}{ Barley } \\
\hline $\begin{array}{l}\text { Spring } \\
\text { Fall }\end{array}$ & 13 & 12 & 8.4 & $0.2^{\mathrm{a}}$ & & & $\begin{array}{l}2.5 \\
8.3\end{array}$ & 1.8 & & \\
\hline \multicolumn{11}{|l|}{ Grasses } \\
\hline Brome & & & & & 93 & 37 & 379 & 60 & & \\
\hline Fescue & & & & & & & 242 & 44 & & \\
\hline Orchard & & & & & 118 & 38 & 81 & 37 & & \\
\hline Oats & 13 & 12 & & & & & & & & \\
\hline Sugar-beet tops & & & & & & & 50 & 12 & & \\
\hline Wheat & 14 & 7 & 19 & & $74^{b}$ & $31^{b}$ & & & & \\
\hline & & & & • & & & & & & \\
\hline a. Apparent ana & cal error. & & & & & & & & & \\
\hline b. Immature sa & os included lec & s, tillers, and & leads of grain. & & & & & & & \\
\hline
\end{tabular}


dissolve and transport soluable salts downward through the soil. Farmers using irrigation water to leach salts from the soil must consider water quality, irrigation management, leaching, and drainage to obtain maximum efficiency.

\section{Water Quality}

Upon evaluating geothermal water for irrigation and soil leaching, it was apparent that reduction of yield would occur unless salt tolerant crops were grown and special management practices maintained a favorable soil-salt balance. Laboratory leaching experiments indicate that new soils may experience increased salinity and decreased permeability when irrigated with geothermal water. Comparisons of soil analysis data from the Udy-1 plot, following 3 years of geothermal irrigation, confirm that soil salinity and exchangeable sodium levels were increased through geothermal-water application. However, satisfactory crops were produced on plot soils using geothermal water, and the salts did not cause significant yield reductions of tolerant crops.

\section{Irrigation Management}

The best methods for applying geothermal irrigation water depend upon crop variety, soil type, topography, water availability, and water quality. The three principal means of irrigation used during this experiment were flood, furrow, and sprinkler.

The surface-flood and furrow methods appear to offer advantages in irrigating salt-sensitive crop varieties. For example, a row of hardwood trees planted along one border of the Udy-1 plot, exhibited satisfactory establishment and growth on the surface-irrigated subplots; whereas the trees planted on the sprinkled subplots experienced severe foliar damage, which resulted in nearly $100 \%$ mortality following foliar exposure to the saline waters.

Flood irrigation offers advantages over furrow irrigation for applying saline water to forage and cereal crops. If the hazard of soil erosion is low, and the topography suitable for uniformly applied flood irrigations over the soil surface; the crop consumptive use and soil leaching requirements may be fully satisfied. In addition, foliar damage will be minimal, and a soil salt balance can be maintained. Furrow irrigation is less desirable than flooding for non-row crops because salts tend to accumulate in the ridges between furrows. Refer back to Table 7 for an indication of the efficiency of sprinkler and furrow irrigation in maintaining soil salt balances, using geothermal and comparison waters. During Phase 3, the surfaceflood subplots were corrugated to provide more efficient irrigation water distribution to high spots. The flood plots were thus changed from flood to furrow, but the subplot title remained unchanged for the sake of uniformity. The higher salinity (ECe) values shown for flood-irrigated subplots indicate that less effective leaching occurred. Under the furrow system, the saline water moved into the ridges between furrows by capillary action; the water evaporated; and the dissolved salts remained in the soil ridges.

Irrigation by sprinkling, although more costly than surface irrigation, allows for uniform water distribution and close control over the amount of water applied. Sprinkling is often used on steep slopes or where the topography is too rough for surface methods. However, there is a general tendency to apply an insufficient amount of water to satisfy the leaching requirements under sprinkler systems, and special effort must be made to maintain a favorable soil salt balance. If geothermal water delivered to the field is hot, sprinkling offers a means of cooling prior to plant contact.

\section{Leaching Requirement}

Field crops derive most of their moisture from the upper portions (top $15 \mathrm{~cm}$ ) of the root zone. Although plants can consume water from anywhere in the root zone, normally about $40 \%$ is obtained from the upper quarter, $30 \%$ from the second quarter, $20 \%$ from the third quarter, and $10 \%$ from the lowest quarter. 9 Thus, the salinity of the lower root zone is considered to be of less importance as long as the crop is relatively well supplied with moisture in the upper, more active root zone. If water in excess of crop requirements is uniformly applied, each irrigation will leach the upper soil area and maintain it at relatively low salinity. Except for salt crusts, salinity will usually increase with depth and be greatest in the lower part of the rooting area. 
Since the geothermal fluids used in this experiment contained appreciable quantities of salts $\left(\sim 1.5 \mathrm{~kg} / \mathrm{m}^{3}\right)$, periodic leaching irrigations were required to remove salts which accumulated as a result of evapotranspiration from root-zone soils. The leaching requirement is defined as the fraction of the irrigation water that must pass through the root zone to prevent the soil salinity from exceeding a specified value. ${ }^{9}$ Assuming steadystate, water-flow rates, uniform application of irrigation water, no rainfall, no removal of salt in the harvested crop, and no precipitation of soluable constituents in the soil, the leaching requirement is simply the ratio of the equivalent depth of the drainage water to the depth of irrigation water (Ddw/Diw), and may be expressed as a fraction or percent. This ratio is equal to the inverse ratio of the corresponding electrical conductivities, that is,

$\mathrm{LR}=\frac{\mathrm{Ddw}}{\mathrm{Diw}}=\frac{\mathrm{ECiw}}{\mathrm{ECdw}} \cdot$

Tolerant crops, such as beets and barley, are capable of producing good yields where the salt concentration of the soil solution may reach $\mathrm{ECe}$ values as high as $8 \mathrm{mmho} / \mathrm{cm}$.

\section{Drainage}

Drainage in agriculture is the process of removing the excess water and salts from the soil to maintain high crop productivity. The irrigation, soil management, and leaching practices employed with high-salinity geothermal water, establish the drainage requirements. The minimum requirement must be adequate to remove a depth of water equivalent to that which must be passed through the soil root zone to maintain a favorable salt balance.

The Raft River plots currently exhibit sufficient natural, internal drainage to accommodate the excess waters applied. However, if large land areas are irrigated with the required leaching fraction, the local water table may rise, leading to complications in salinity control; the ground water may be impacted by leachates; and drainage problems may result.

Continuing phases of this experiment will concentrate on determining and applying the proper leaching irrigations to plot soils, characterizing the resultant soil profiles, and determining the quality of the leachates which reenter the natural aquifer system.

\section{Crops}

\section{Growth and Yields}

During Phase 2, barley growth patterns on the Udy-2 plot were variable, a result of uneven leaching of soil salts. Figures 4 and 5 show a comparison to two areas on the barley plot where one received adequate and the other inadequate leaching. The crop quality did not appear to be affected by the irrigation water source. Figure 6 shows typical cereal grains irrigated with geothermal and comparison waters. The growth and yields of barley and sugar beets irrigated with geothermal water were not 'restricted by the soil and water salinity, as evidenced by yield comparisons with the surrounding area farms.

The forage crops planted on the subplots included monoculture alfalfa and a forage mixture consisting of alfalfa, smooth brome, alta fescue, and orchard grass. The alfalfa on all of the sprinkled subplots exhibited varying degrees of leaf curl and tip burn. Moisture stress associated with the saline soils and water and other factors such as nutrient deficiencies may have prompted this reponse. However, none of these symptoms appear to severely retard total growth and yields. The forage grasses exhibited satisfactory establishment, growth, and productivity on each of the subplots. Figures 7 and 8 show the relative growth of forage on geothermal- and comparison-water sprinkled subplots. Figure 7 shows a portion of the subplot located on Ayses-Hiko Peak-Complex soil, which is not well suited for irrigated agriculture, and is therefore inherently less productive than the Bram, silt-loam soil on the remainder of the plot.

\section{Fluoride}

Fluoride is present in various amounts in all soils and natural waters. All vegetation contains some fluoride that has been taken up from soils, absorbed through the leaves from the air, or sprinkled by irrigation water.

There is little detailed information available on the amount or mechanism of fluoride uptake from 


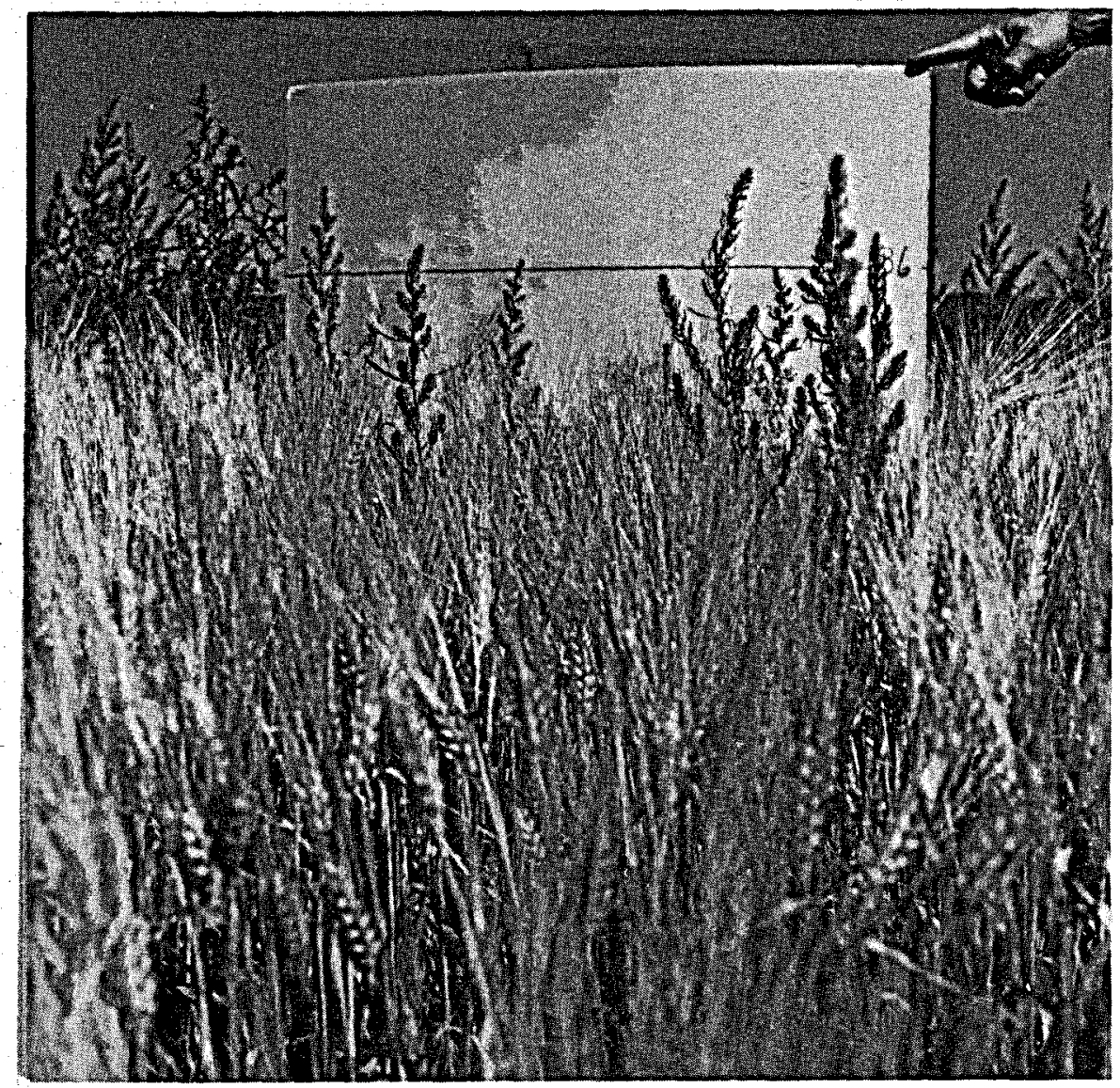

Figure 4. Barley plot sprinkled by geothermal water, showing good growth near sprinkler lines where soils were leached effectively.

irrigation water by plants. Investigators have reported that fluorides can be absorbed from the soil solution or directly through the leaves. 10,11 Rand and Schmidt 12 reported elevated fluoride content of forage grown with irrigation water containing $6.2 \mathrm{ppm}$ fluoride.

The natural concentration of fluoride in the foliage of most plants is in the range of 2 to $20 \mathrm{ppm}^{8}$ The fluoride concentrations of 107 samples of alfalfa from different U.S. areas that are assumed to be free of industrial pollution, ranges from 0.8 to $36.5 \mathrm{ppm}$, with a mean of $3.6 \mathrm{ppm} .13$

Results from the experiment indicate that cereal grains sprinkled with geothermal water may exhibit high fluoride contents on their surfaces, but that fluorides are apparently not translocated from the roots, leaves, and tillers to the grain. Therefore, there is little likelihood of having high fluoride in the grain, even when sprinkled with high fluoride water.
There is strong evidence, however, that fluorides are absorbed by forage crops when sprinkled with water containing fluorides. Nonetheless, further evidence indicates that geothermal water containing fluoride can be used for surface irrigation without greatly increasing the fluoride content of the forage being grown.

From our observations, it seems likely that frequent sprinkler applications of irrigation water at low rates of application during hot weather and low humidity are all conducive to high absorption of fluoride by the foliage of crops. In contrast, high water volumes applied infrequently during the cool of the night are conducive to lower fluoride adsorption. Further, there is little likelihood of having high levels of fluoride in the forage or grain crops when the waters are applied by surface irrigation.

The fluoride levels exhibited by forage crops sprinkled by geothermal water may be high enough to produce toxic effects in consuming 


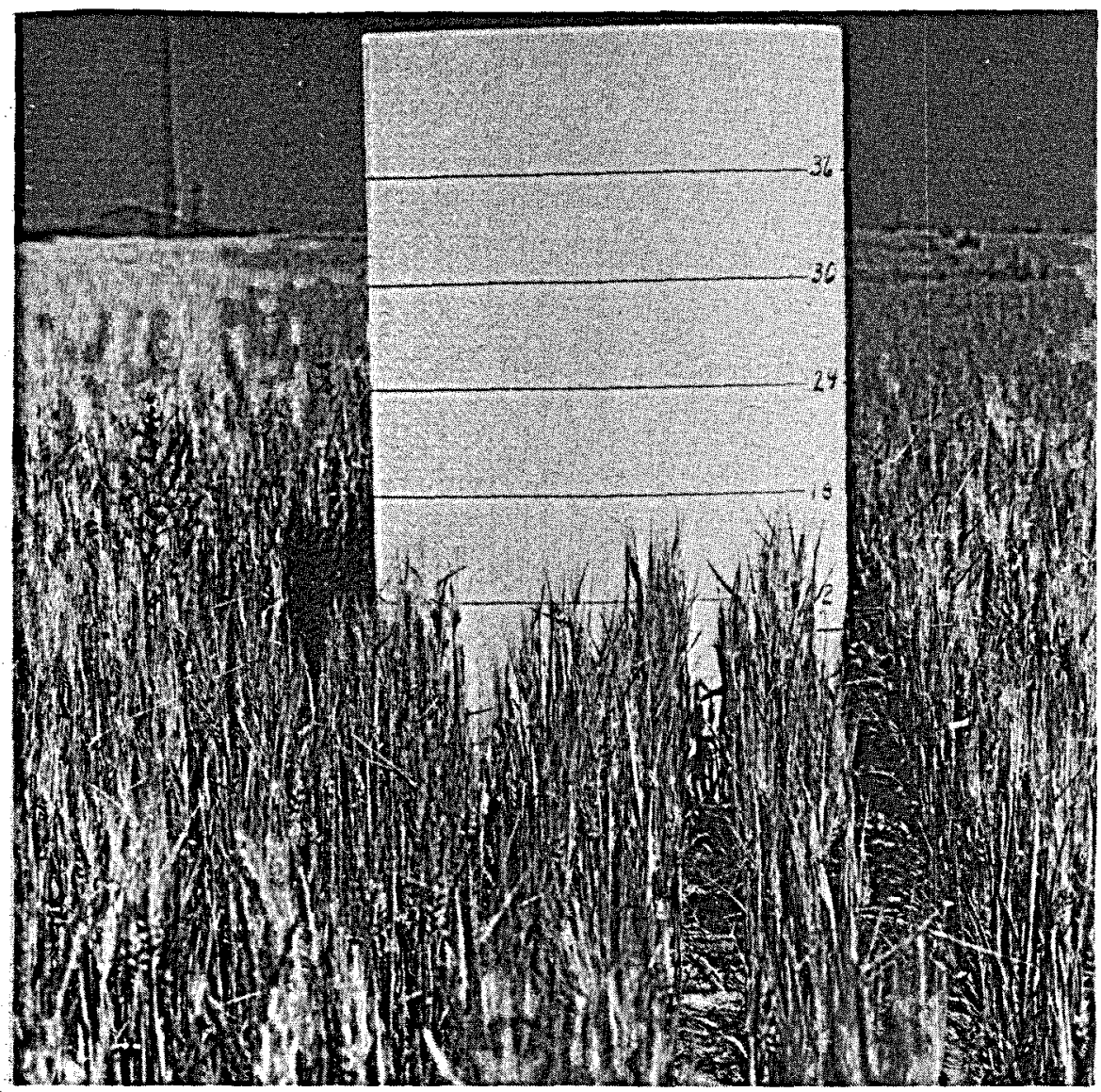

Figure 5. Barley plot sprinkled by geothermal water, showing poor growth midway between sprinkler lines where soils were not leached effectively.

livestock, if fed as the major source over a prolonged period of time, or if the water supply available to the consuming animals also contains fluorides. Livestock feeders using geothermalsprinkled forage as a feed source should take steps to blend high and low fluoride feeds and provide low fluoride water to the animals during the feeding program.

\section{CONCLUSIONS AND RECOMMENDATIONS}

Agricultural irrigation offers a potential alternative to dispose of energy-expended, Raft River geothermal water. Such irrigation may reduce reinjection costs and provide an additional water source to the arid Raft River region. Soils receiving geothermal water may experience increased salinity and decreased permeability, such that leaching irrigations must be applied to maintain a favorable soil salt balance. Barley, forage, and sugar-beet crops produced satisfactory growth and yields, with no apparent reduction in nutritional value from exposure to geothermal water. Cereal grains and surfaceirrigated forage crops did not absorb and translocate appreciable quantities of fluoride; but geothermal-sprinkled forage crops exhibited abnormally high fluoride levels. 


\section{RAFT RIVER IRRIGATION EXPERIMENT Typical Grains}
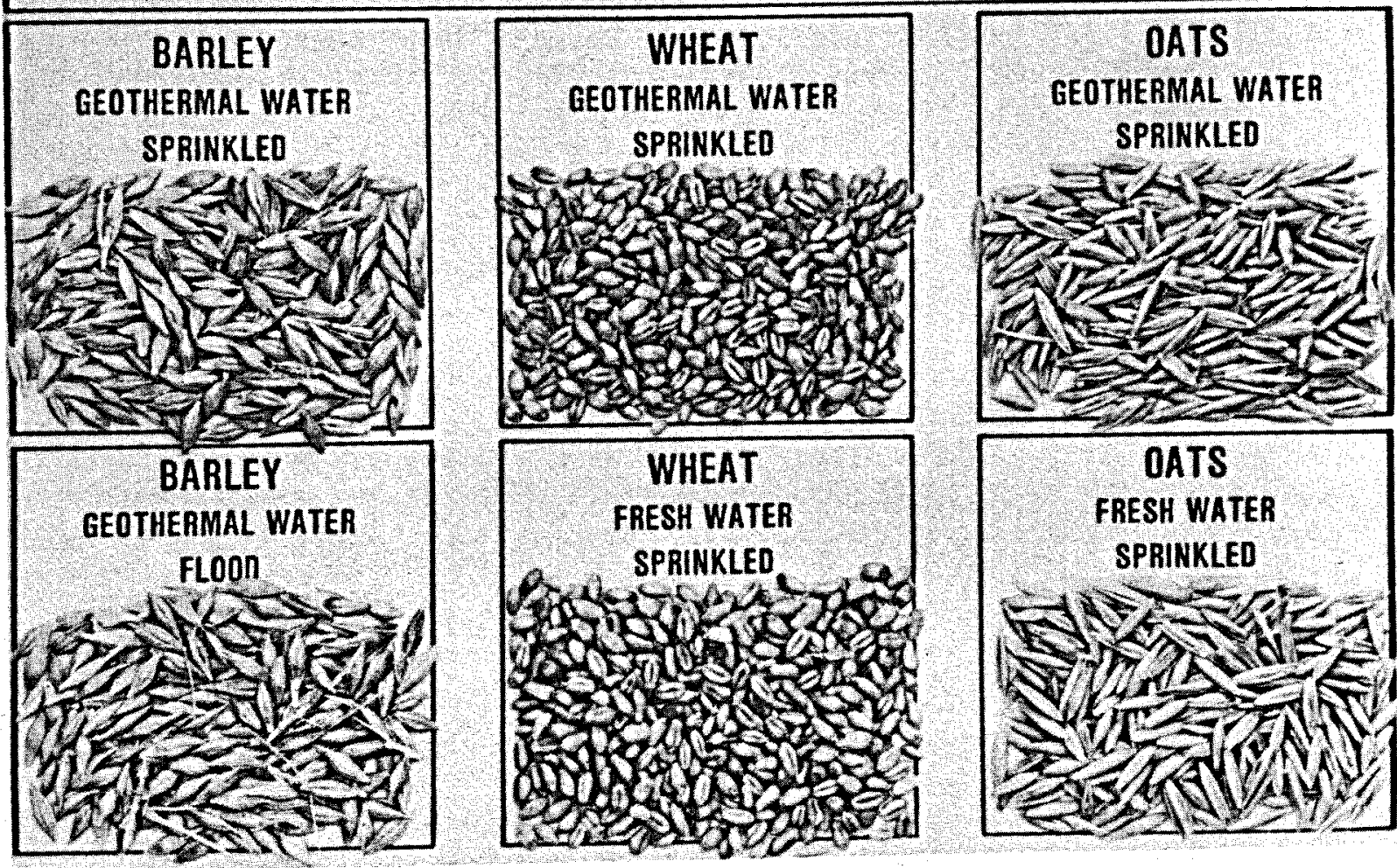

Figure 6. Typical threshed grains from experiment.

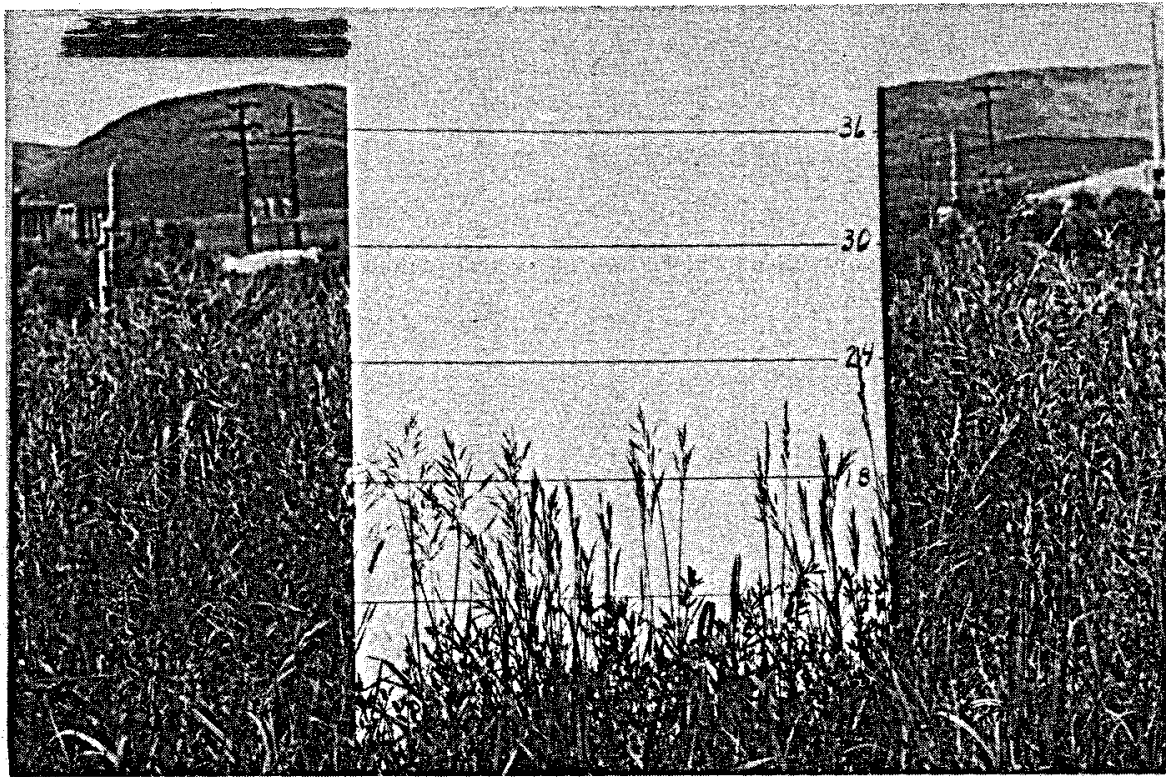

Figure 7. Forage subplot sprinkled by geothermal water on soll at Ayses-Hiko Peak Complex. 


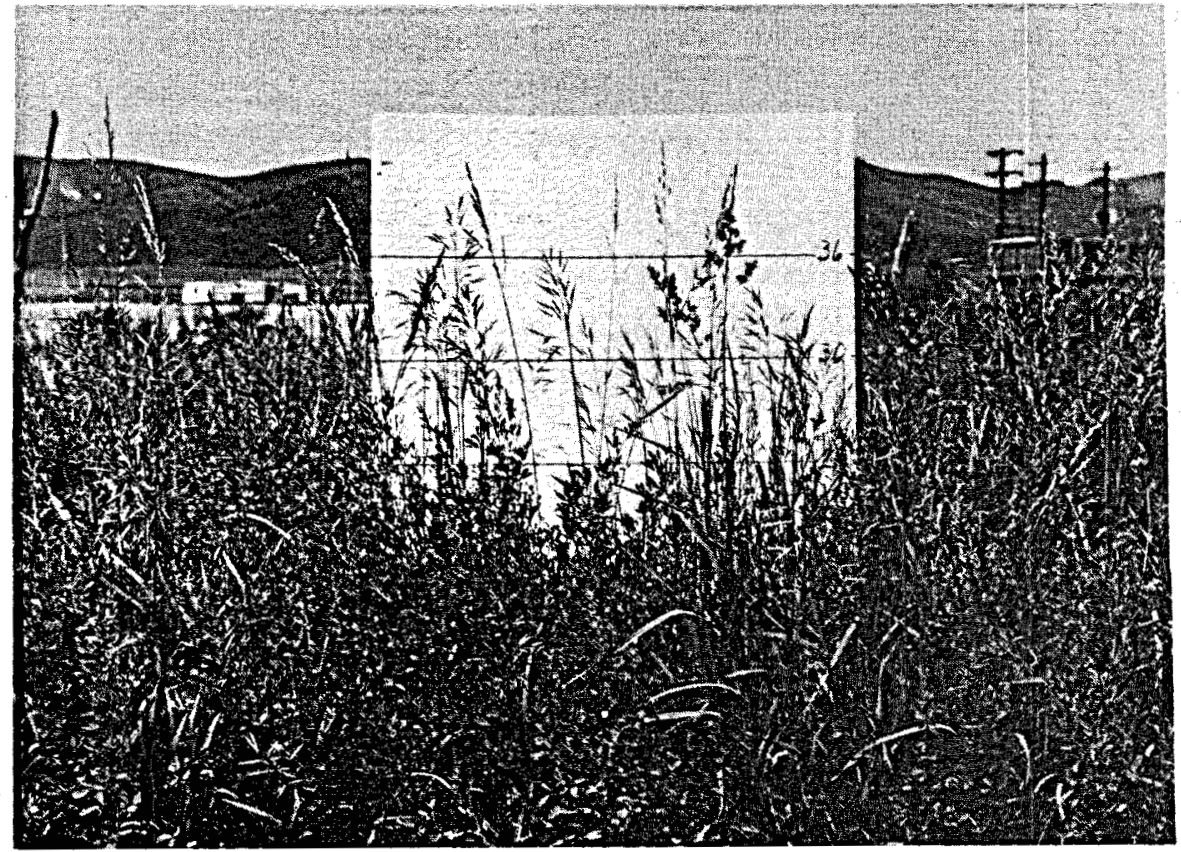

Figure 8. Forage subplot sprinkled by comparison water, showing good growth of alfalfa and grasses on Bram, silt-loam soil. 


\section{REFERENCES}

1. R. C. Schmitt and S. G. Spencer, Beneficial Uses of Geothermal Energy; Description and Preliminary Results for Phase I of the Raft River Irrigation Experiment, TREE-1048, January 1977 , pp. 1-41.

2. N. E. Stanley, Raft River Irrigation Experiment Phase 2 Report, GP-03-79, February 1979, pp. 1-22.

3. R. J. Sutter and G. L. Corey, "Consumptive Irrigation Requirements for Crops in Idaho," University of Idaho Agricultural Experiment Station Bulletin, 516, 1970, pp. 90-91.

4. D. W. Thorne and H. B. Peterson, Irrigated Soils, 2nd ed., Philadelphia: Blakiston Company, 1949.

5. N. L. Kent, Technology of Cereals, Elmfford, New York: Pergamon Press, Inc., 1966, pp. 37-193.

6. D. F. Miller, Composition of Cereals, Grains and Forages, National Academy of Sciences-National Research Council, Publication 585, 1958, pp. 1-385.

7. Idaho Crop and Livestock Reporting Service (compiler), Idaho Agricultural Statistics 1978, USDA Economics, Statistics and Cooperative Service, 1978.

8. Division of Medical Sciences National Research Council, Biologic Effects of Atmospheric Pollutants-Fluorides, Washington, D.C.: National Academy of Science Printing and Publishing Office, 1971, pp. 77-132.

9. United States Department of Agriculture, Diagnosis and Improvement of Saline and Alkali Soils, USDA Agriculture Handbook No. 60, Washington D.C.: U.S. Government Printing Office, 1969.

10. I. A. Leone, E. Brennan, R. H. Daines, W. R. Robbins, "Some Effects of Fluorine on Peach, Tomato, and Buckwheat when Absorbed Through the Roots," Soil Science, 66, 1948, pp. 259-266.

11. R. F. Brewer, F. H. Sutherland, F. B. Bukllemet, "Sorption of Fluorine by Citrus Foliage," Journal of the American Society for Horticulture Science, 76, 1960, pp. 215-219.

12. W. E. Rand and H. J. Schmidt, "The Effect upon Cattle of Arizona Waters of High Fluoride Content," American Journal of Veterinary Research, 13, 1952, pp. 50-61.

13. J. W. Suttie, "Fluoride Content of Commerical Dairy Concentrates and Alfalfa Forage," Journal Agricultural and Food Chemistry, 17, 1969, pp. 1350-1352. 
DISTRIBUTION RECORD FOR EGG-2005

Internal Distribution

$$
\begin{aligned}
& 1 \text { - Chicago Patent Group - DOE } \\
& 9800 \text { South Cass } \\
& \text { Argonne, IL } 60439 \\
& 1 \text { - H. P. Pearson } \\
& \text { Information Processing - EG\&G } \\
& 6 \text { - INEE Technical Library } \\
& 75 \text { - Author }
\end{aligned}
$$

\section{External Distribution}

$$
\begin{aligned}
441-U C-66 g & \text { - GE--Direct Applications of Heat from Geothermal } \\
\text { Resources } & \text { U. }
\end{aligned}
$$

Total Coples Printed: 524 